\title{
PERAN WANITA DALAM PENDIDIKAN ANAK PERSPEKTIF ISLAM
}

\author{
Oleh: NURLINA \\ Dosen Tetap Pada Jurusan Tarbiyah Stain Watampone \\ email: dikatakbir@yahoo.co.id
}

\begin{abstract}
:
This paper examines the role of women in the education of children in the Islamic perspective that the role of women against children is very large in the formation of future generations. Given the magnitude of opportunities and opportunities of women as a mother role in initiating the process of education of children from an early age. The potential and ability of Muslim women is very influential to shape the colors and patterns of future generations of Muslims. Therefore, as a woman is expected to have a love that manifestly manifests in the way of raising, hugging, meet needs and make friends with children. Therefore women should seek to be a smart woman as a provision to educate their children, because a smart mother will give birth to intelligent children. Creating a great generation there are points that need to be a record for a woman to be played to her child that is aqidah, morals and prayers. Then the intelligence, tenacity, and the mother's temperament is the dominant factor for the child's future. That is the word of the wise man of old, If there are men who become scholars, scholar, prominent figures or warrior heroes, See who their mother is. Because Mother has a big role in shaping one's character and knowledge. Therefore, the mother is the center of children's education.
\end{abstract}

\section{Abstrak:}

Tulisan ini mengkaji tentang peran wanita dalam pendidikan anak persfektif Islam bahwa peran wanita terhadap anak sangat besar dalam pembentukan generasi di masa datang. Mengingat besarnya peluang dan kesempatan wanita sebagai seorang ibu berperan mengawali proses pendidikan anak-anaknya sejak dini. Potensi dan kemampuan para wanita muslimah sangat berpengaruh besar membentuk warna dan corak generasi umat Islam di masa datang. Karena itu sebagai seorang wanita diharapkan memiliki kasih yang secara nyata terwujud dalam cara membesarkan, memeluk, mencukupi kebutuhan dan berteman dengan anak. Karena itu wanita harus mengupayakan diri untuk menjadi wanita yang pintar sebagai bekal untuk mendidik anak-anaknya, karena seorang ibu cerdas akan melahirkan anak-anak yang cerdas. Untuk menciptakan generasi hebat ada poin yang perlu menjadi catatan bagi seorang wanita untuk diperankan kepada anaknya yaitu akidah, akhlak dan sholat. Maka kecerdasan, keuletan, dan perangai sang ibu adalah faktor dominan bagi masa depan anak. Demikianlah kata orang bijak tempo dulu, jika ada lelaki yang menjadi ulama, cendikia, tokoh ternama atau pahlawan ksatria, lihatlah siapa ibu mereka. Karena Ibu memiliki peran besar dalam membentuk watak dan pengetahuan seseorang. Karena itu ibu merupakan sentra pendidikan anak.

\section{Kata Kunci: Peran, Wanita, Pendidikan, Watak}

\section{PENDAHULUAN}


Kalau kita berbicara tentang mendidik anak, maka itu bukanlah kewajiban wanita saja, namun kaum Adam memiliki tanggungjawab tidak kalah besarnya dalam mendidik anak. Lihatlah di dalam Surat Luqman, Allah menceritakan bagaimana Luqman sebagai seorang bapak menasihati anaknya. Juga di dalam surat Al-Baqarah, tentang Nabi Ibrahim berdoa untuk anak cucunya agar mereka menjadi ummat yang tunduk dan patuh kepada Allah. Hal ini menunjukkan bahwa mendidik dan mendoakan anak adalah kewajiban kedua orangtua.

Namun seharusnya wanita memiliki peran yang lebih besar dalam mengasuh anak. Karena wanitalah yang melahirkannya, kemudian menyusuinya selama dua tahun jadi proses pendidikan pada anak dari seorang wanita bisa memulai pada anaknya sejak janin (masih dalam kandungan). Minimal yang harus dilakukan seorang wanita terhadap janin dalam kandungannya adalah memilihkan makanan yang halal dan baik untuk membesarkan janin. Senantiasa berdzikir dan berdo'a kepada Allah SWT, ketika merasakan ada gejala tentang keberadaan janin. Tidak mengeluh terhadap rasa sakit yang dialaminya di saat hamil, tetapi sepenuhnya berserah diri kepada Allah dan senantiasa mengharapkan pertolongan Allah agar tetap bisa menunaikan segala kewajiban dan tanggung jawab yang dibebankan kepadanya sebagai seorang wanita. Berupaya menenangkan perasaan/emosionalnya dengan membaca ayat-ayat Al Qur'an, sehingga suasana hatinya tetap tenang dan ikhlas menjalani masa kehamilannya. Sebab kondisi psikologis seorang ibu menurut pendapat para ahli akan berpengaruh pada perkembangan janin yang dikandungnya.

Begitu pun saat anak lahir ke dunia, ibu berperan besar untuk menciptakan kondisi lingkungan tempat anak dibesarkan. Suara apa yang pertama didengarnya ketika pertama kali anak bisa mendengar. Pemandangan seperti apa yang dilihatnya ketika anak pertama kali melihat. Kata-kata apa yang diucapkan ketika anak pertama kali berbicara. Dan lingkungan pertama yang masuk ke dalam memori otak yang masih polos seorang anak adalah rumahnya. Apa-apa yang ada di dalam rumahnya itulah yang pertama direkamnya, terutama yang paling dekat kepadanya adalah ibu. Oleh karena itu wanita adalah madrasah pertama bagi anakanaknya.

Jadi tak dapat dipungkiri bahwa peran wanita terhadap anak sangat besar dalam pembentukan generasi di masa datang, mengingat besarnya peluang dan kesempatan wanita sebagai seorang ibu berperan mengawali proses pendidikan anak-anaknya sejak dini. Potensi dan kemampuan para wanita muslimah sangat berpengaruh besar membentuk warna dan corak generasi umat Islam di masa datang. Karena itu sebagai seorang wanita diharapkan memiliki 
kasih yang secara nyata terwujud dalam cara membesarkan, memeluk, mencukupi kebutuhan dan berteman dengan anak. Maka wanita harus mengupayakan diri untuk menjadi wanita yang pintar sebagai bekal untuk mendidik anak-anaknya, karena seorang ibu cerdas akan melahirkan anakanak yang cerdas.

\section{PEMBAHASAN}

\section{A. Pentingnya Peran Wanita}

Wanita memegang peran yang sangat penting dan peran tersebut bersifat abstrak. Seperti sang pelatih yang mengatur para pemainnya, karena itu wanita memiliki peran yang signifikan untuk mencetak generasi yang cerdas dan berakhlak serta berwatak yang baik. Kehidupan dalam keluarga merupakan titik awal untuk menuju kehidupan bernegara. Anak yang terlahir dalam keluarga yang terdidik tentu akan berbeda nilainya dibandingkan anak tanpa perhatian orangtuanya, khususnya dari ibu. Karena secara psikologis perempuan memiliki sifat kasih sayang yang tinggi. Peran wanita sebagai ibu sangat berarti dan kiprahnya tak bisa dipandang sebelah mata.

Berawal dari pendidikan di keluarga, wanita mulai mengepakkan sayapnya. Start yang sempurna akan mempengaruhi hasil akhir dalam suatu perlombaan. Di bawah ini poin yang perlu menjadi catatan bagi seorang wanita untuk menciptakan generasi hebat:

1. Akidah

Pengetahuan yang pertama kali di kenalkan ke anak-anak kita adalah seputar tauhid yakni upaya sang anak untuk mengetahui dan meyakini akan Tuhan semesta alam. Mereka harus memahami siapa yang memberinya kehidupan, yang menciptakan mereka. Akidah merupakan faktor yang paling urgen dalam kehidupan ini, karena iman merupakan fundamental sekali. Oleh karena apabila dilandasi oleh akidah yang kuat, anak mengerti akan kebenaran dan benteng akidah tidak akan goyah begitu saja di tengah maraknya aliran yang muncul ke permukaan bumi. Jadi anak harus diperkenalkan akidah secara ijmali (global) dulu, yakni berupa penjelasan tentang akidah yang harus diketahui oleh setiap Mu'min dan rukun iman yang lainnya.

2. Akhlak

Anak balita memiliki tingtat kecerdasan yang cukup tinggi untuk menangkap sesuatu di lingkungannya. Kepekaan dan daya tangkap yang dimiliknya mampu menirukan apa yang dilihat 
olehnya. Perilaku yang baik dari orang tua dalam keseharian bisa menjadi faktor utama dalam pengembangan karakter dan kpribadian yang baik bagi balita.

Karena itu mulailah dari hal kecil, semisal membiasakan anak salam ketika hendak pergi dan bersalaman dengan orang tua, membaca basmalah sebelum makan, mengggunakan tangan kanan ketika mengambil dan memegang sesuatu.

Akhlak merupakan sebuah karakter yang melekat dalam hati, kebiasaanlah yang akan membentuknya. Maka kondisi yang harmonis dalam lingkungan keluarga diharapkan sekali demi terbentuknya generasi yang bermoral dan bermartabat.

\section{Sholat}

Ibadah adalah hal yang paling urgen dalam menjalin komuniksi dengan sang Ilahi Rabbi, disamping kita juga tidak boleh mengesampingkan kehidupan sosial. Ibadah yang paling mendasar adalah pengenalan tentang sholat di usia dini dan diperlukan juga pembelajaran yang intens sejak dini. Dengan tujuan melatih supaya terbiasa dan tidak terlalu berat ketika sudah dewasa.

Perhatian orang tua diharapkan tidak hanya fokus dalam pendidikan umum, pendidikan agama juga harus diimbangi untuk membentuk generasi yang bermoral karena merupakan pondasi umum untuk mendidik sang buah hati, diharapkan bisa mencetak generasi yang berkpribadian Islam.

Karena tugas seorang wanita sebagai ibu selama ini hanya 3M (Memasak, Mencuci dan Melayani), namun itu sudah zaman dahulu sehingga tugas ibu juga harus diperbarui dengan istilah mantap yang artinya harus cerdas, kreatif, dan peduli. Perempuan pintar tidak harus melalui sekolah formal, tetapi bisa belajar dari lingkungan. Melihat perkembangan di era globalisasi ini sangat cepat jika tidak diikuti dengan arahan ibu, maka anak-anak akan kehilangan arah dan panutan. Sehingga ketika anak bingung atas pengambilan keputusan, maka peran ibu menjadi penting dengan berbagai pengalaman hidupnya. ${ }^{1}$

\section{B. Wanita Sentral Pendidikan Anak}

Orang tua menjadi poin penting dalam pendidikan anak dalam sebuah keluarga. Bahkan peran ini harus diperhatikan sejak anak masih dalam kandungan. Hal ini diutarakan Menteri Pendidikan dan Kebudayaan (Mendikbud) Muhajir Effendy dalam Milad ke-100 Aisyiyah di

\footnotetext{
${ }^{1}$ www.antaranews.com. pendidikan Ibu Jadi Kunci Sukses Anaknya.
} 
Gedung B Kampus Universitas Aisyiyah Yogyakarta. ${ }^{2}$ Menurut Muhadjir, pendidikan anak sudah dimulai sejak dalam kandungan. Hal sesuai Al-quran yang menyebut pendidikan dimulai dalam kandungan. Dalam hal ini, disebutkan bahwa orang tua khususnya ibu menjadi bagian penting dalam pendidikan anak.

Muhadjir menyebut peran keluarga atau orang tua sangat penting dalam pendidikan anak. Karena pedidikan itu dimulai dari pendidikan ibu. Untuk itu saya mendorong parenting education. Pendidikan orang tua untuk bisa menyiapkan pendidikan anaknya sejak dari kandungan dengan pemberian makanan yang sehat.

Maka kecerdasan, keuletan, dan perangai sang ibu adalah faktor dominan bagi masa depan anak. Demikianlah kata orang bijak tempo dulu. Jika ada lelaki yang menjadi ulama, cendikia, tokoh ternama atau pahlawan ksatria, lihatlah siapa ibu mereka. Karena Ibu memiliki peran yang penting dalam membentuk watak, karakter, dan pengetahuan seseorang. Karena itu ibu merupakan sentra pendidikan anak.

Menurut Ki Hajar Dewantoro bahwa suasana kehidupan keluarga merupakan tempat yang sebaik-baiknya untuk melakukan pendidikan individu maupun sosial. Oleh karena itu keluarga adalah tempat pendidikan yang sempurna untuk melangsungkan pendidikan kearah penbentukan pribadi yang utuh. ${ }^{3}$

Karena itu orang tua adalah orang yang pertama memikul tanggung jawab pendidikan terhadap anak, secara alami anak pada masa-masa awal kehidupannya berada ditengah-tengah ayah dan ibunya sehingga dasar-dasar pandangan hidup, sikap hidup serta ketrampilan hidup banyak tertanam sejak anak berada ditengah-tengah orang tuanya.

Dalam hadits Nabi SAW secara jelas Beliau mengisyaratkan lewat sabdanya yang artinya: "Setiap anak dilahirkan dalam keadaan suci, maka orang tuanyalah yang dapat menjadikannya Yahudi, Nasrani atau Majusi". 4

Berdasarkan hadits tersebut jelaslah bahwa anak dilahirkan dalam keadaan suci, maka mendidiknya sudah menjadi tanggung jawab orang tua. Orang tua berkewajiban mendidik anakanaknya dalam hal pendidikan agama dan umum termasuk didalamnya pendidikan ketrampilan, hal ini dimaksudkan agar kelak anak-anak itu akan dapat mencapai kebahagiaan hidup di dunia dan akherat.

\footnotetext{
${ }^{2}$ News.liputan6.com. Peristiwa.

${ }^{3}$ Abu Ahmadi, Nur Uhbiyati, Ilmu Pendidikan (Jakarta: Rineka Cipta.

${ }^{4}$ Kitab B. Marom yang dikutib oleh Zuhairi, dkk, Filsafat Pendidikan Islam (Jakarta: Bumi Aksara, 1992),
} 
Sebagaimana isi surat An-Nisa berikut:

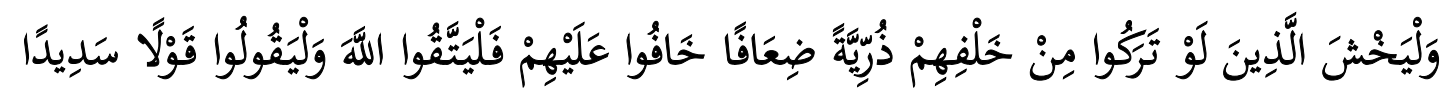

Artinya: "Dan hendaklah orang-orang takut kepada Allah, bila seandainya mereka meninggalkan anak-anaknya, yang dalam keadaan lemah, yang mereka khawatirkan terhadap (kesejahteraan) mereka. Oleh sebab itu, hendaklah mereka bertakwa kepada Allah dan mengucapkan perkataan yang benar". (an-Nisa': 9)

Namun realitasnya banyak ibu yang tidak dapat melaksanakan tugas dan tanggung jawabnya dengan baik. Mungkin sebagian terlalu sibuk dengan kariernya hingga terkadang seperti menyerahkan tanggung jawab terbesar dalam pendidikan kepada pihak sekolah atau anakanak yang lebih banyak menghabiskan waktu dengan pengasuh yang bisa jadi kurang berkualitas. Atau mungkin ada yang merasa menyerah dan putus asa dalam mendidik anak karena kurang pengetahuan sehingga bingung tidak mengerti dengan apa yang harus dilakukan.

Jika kondisi ini terus berlanjut maka pendidikan dan perkembangan jiwa anak yang kurang mendapatkan pengasuhan yang baik dari seorang Ibu akan terabaikan sehingga kepribadian anak yang baik tidak akan tercapai. Biasanya perilaku anak seperti ini menjadi buruk baik di keluarga maupun masyarakat.

Jadi hal pertama yang harus diciptakan oleh keluarga terutama oleh seorang Ibu adalah menciptakan situasi dan kondisi yang kondusif sehingga kendala dalam mendidik anak, mengarahkan mereka terhadap ajaran agama, menciptakan kepribadian yang salih akan lebih mudah, karena ada saling percaya dan ikatan kasih sayang yang kuat antara Ibu dan anak, dari seluruh pihak keluarga. Berikut beberapa cara yang perlu dilakukan orangtua dalam melakukan peran mendidik anak terutama wanita sebagai seorang ibu.

\section{Mengenal Sifat - Sifat Anak}

Setiap anak membawa sifat masing-masing. Berikut sifat-sifat anak yang sebaiknya diketahui orang tua serta cara menghadapi anak-anak mereka.

a. Egois

Sifat egois atau keras kepala seringkali memang membuat orang tua kehilangan kesabaran. Anak yang egois umumnya mau menang sendiri, tidak mau mendengarkan orang lain dan harus dituruti semua keinginannya. Bila tidak dipenuhi segala jurus ancaman pun akan ia lontarkan, mulai dari mogok makan, tak mau belajar sampai berguling-guling di lantai.

Yang harus dilakukan jangan panik bila menghadapi anak yang egois. Tak perlu marah, hadapi dengan lembut dan sabar. Banyak cara bisa dilakukan untuk menghadapi anak 
bertemperamen keras. Yang terpenting adalah memberikan pengertian dan pengarahan. Karena umumnya anak-anak belum dapat membedakan mana yang baik dan buruk. Yang ada dalam pikiran mereka adalah mengerjakan atau melakukan sesuatu hanya untuk kesenangannya. Jadi, tugas Anda sebagai orang tua adalah memberikan pengarahan dan pengertian pada si anak. b. Perajuk

Ciri anak perajuk adalah suka manja dan cenderung cengeng. Hampir sama dengan anak egois, hanya saja anak perajuk belum tentu keras kepala. Biasanya anak akan marah bila orang tua kurang memberikan perhatian padanya. Misalnya, "Ma, rambut Ella bagus enggak dikuncir seperti ini?" Karena sang mama tidak memberikan komentar dan hanya menggangguk, anak pun marah karena merasa tidak diperhatikan.

Yang harus dilakukan sama seperti menghadapi anak egois, menghadapi anak yang sifatnya suka marah juga butuh kesabaran. Jika tidak, emosi Anda sebagai orang tua bisa terpancing. Mungkin bagi kita, menggangguk saja sudah cukup, namun bagi anak lain lagi. Ia perlu action dari Anda. Anda bisa mengatakan misalnya, "Oh, bagus sekali. Coba Mama lihat kucirnya. Hmm... ternyata anak Mama sudah pintar menguncir rambut sendiri!” Perhatian dan komentar Anda akan membuat anak senang. Bila anak gampang merajuk, cobalah untuk membujuknya. Jangan dengan kekerasan karena hal itu justru akan berdampak tidak baik bagi perkembangan jiwanya.

c. Pemalas

Sifat anak yang pemalas biasanya tidak mau mengerjakan pekerjaan atau tugas yang diberikan padanya. Misalnya merapikan tempat tidur, buku pelajaran atau mainannya. Ia mengandalkan orang lain untuk mengerjakannya.

Yang harus dilakukan, beri anak pengertian dan contoh. Misalnya, setelah bangun tidur, tempat tidur harus dirapikan. Ajak anak untuk turut serta melakukan kegiatan tersebut. Walaupun mungkin di rumah ada pembantu, berikan pengertian pada anak bahwa tidak selamanya ada "si mbak" yang bisa membantunya. Ajar anak-anak untuk memiliki tanggungjawab sejak dini. Bukan pekerjaan berat, cukup yang ringan saja. Seperti merapikan tempat tidur, mainan ataupun rak buku pelajaran.

d. Nakal

Sifat nakal atau bandel wajar dimiliki oleh anak-anak. Biasanya mereka cenderung aktif, usil dan tak takut bahaya. Selain itu, anak umumnya juga punya banyak akal. Contoh perilaku 
mereka antara lain hobi berkelahi, mengejar layang-layang, memanjat pohon tinggi, jahil pada temannya dan sebagainya.

Yang harus dilakukan, tak perlu memarahi atau melarangnya bermain. Coba pantau kegiatannya sehari-hari. Sejauh yang dilakukannya tidak membahayakan dirinya dan orang lain, kenapa harus dilarang? Biarkan mereka melakukannya karena hal itu akan menjawab rasa penasarannya. Lain hal jika yang dilakukan anak membahayakan dirinya dan orang lain. Tak ada salahnya menegur dan memberi pengertian pada anak. Yang terpenting dalam menghadapi anak nakal adalah jangan bosan menasihati dan membimbingnya. Arahkan anak agar menjadi anak yang baik dan sopan.

e. Pendendam

Ciri anak pendendam adalah "menyimpan rasa sakit hati dan berusaha membalasnya di kemudian hari. "Awas, besok kubalas kamu!” begitu biasanya mereka mengancam. Biasanya, anak baru merasa puas bila sudah dapat membalas rasa sakit hatinya.

Yang harus dilakukan, yang utama, jangan biarkan sifat pendendam bersarang dalam diri anak-anak. Pasalnya sifat ini bisa merusak mental mereka. Anak akan berpikir bahwa apa yang dilakukannya benar. Berikan pengertian pada anak bahwa sifat mendendam itu tidak baik. Selain dilarang agama, nantinya juga akan membuat mereka dijauhi oleh teman-teman mereka. Tanamkan pada diri anak bahwa tidak selamanya kejahatan harus dibalas dengan kejahatan.

f. Pemalu

Menutup diri, tak banyak bicara, itulah sebagian ciri-ciri dari anak pemalu. Seorang anak pemalu jarang sekali memulai pembicaraan sebelum diajak berbicara oleh orang lain. Pribadinya sangat tertutup, sehingga sulit menebak isi hatinya. Selain itu, anak pemalu juga terkesan kuper alias kurang pergaulan. Mereka juga akhirnya jarang bergaul dan berkomunikasi dengan lingkungan sekitarnya.

Yang harus dilakukan, cara tepat menghadapi anak pemalu adalah melatih dirinya agar berani tampil dan berbicara di depan umum. Misalkan dengan mengikutsertakan dalam kegiatan sekolah, seperti tari, karate ataupun vokal grup. dengan begitu, mereka akan terbiasa berhadapan dengan orang banyak. Hal ini akan membantu anak untuk berinteraksi dan mengemukakan pendapatnya. Ini juga akan membuat ruang lingkup pergaulannya menjadi luas. Dengan demikian, diharapkan anak tak lagi menjadi pribadi yang tertutup.

g. Periang 
Lincah, ramah dan senang bergaul merupakan ciri-ciri anak yang periang. Umumnya, anak periang memiliki banyak teman, karena kepribadian mereka yang hangat. Mereka memang senang bersahabat. Jarang sekali murung dan selalu bergembira.

Yang harus dilakukan. Meski sifat periang lebih banyak memberikan nilai positif dalam kehidupan sehari-hari, seorang ibu perlu mengingatkan anak agar dapat menempatkan diri kapan harus gembira dan kapan turut merasakan duka orang lain. Beritahu, bila ada temannya yang sedang bersedih, sebaiknya jangan bergembira. Jadi pintar-pintarlah menempatkan diri. ${ }^{5}$

Karena itu, untuk membentuk karakter anak yang baik hendaklah dimulai ketika mereka masih kecil atau bahkan sejak masih janin. Karena anak-anak cenderung akan meniru apa saja yang dilakukan orang terdekatnya. Jika ibu sering memperlihatkan perbuatan baik kepada anaknya, secara tak sengaja sang anak akan merekam apa yang dilihatnya. Menjadi teladan yang baik bagi anak tidaklah semudah membalikan telapak tangan. Tetapi bila perilaku positif sudah jamak dilakukan dalam kehidupan keseharian maka teladan bisa diberikan bahkan tanpa perlu bersusah payah. Karena orang tua yang dapat memberi contoh kepada anak bagaimana berperilaku yang baik seperti tidak suka berbohong, bersifat adil, mencintai sesama, tekun belajar, berdisiplin dan lain lain. Menjadi teladan adalah salah satu cara bagi orang tua khususnya ibu untuk menulisi anaknya sebagai kertas yang masih polos. Memberi teladan yang baik tidak hanya berguna di masa anak-anak saat itu saja tetapi akan bermanfaat kelak saat si anak sudah mencapai umur dewasa dan telah berada di tengah-tengah masyarakat. Jadi tidak salah lagi kalau wanita adalah tiang negara, jika baik wanitanya maka baiklah negaranya dan jika rusak wanitanya maka rusak pula negaranya.

\section{PENUTUP}

Dari uraian-uraian tersebut di atas maka dapat disimpulkan bahwa peran wanita sebagai seorang ibu yang merupakan madrasah (sekolah) pertama dan utama bagi anak-anaknya. Jadi tak dapat dipungkiri peran Ibu dalam mendidik anak-anak sangatlah penting. Karena sejak dalam kandungan seorang anak sudah bersama ibunya. Awal ia mendengar dan merasakan semua sudah berlangsung sejak sudah berada didalam rahim seorang Ibu.

\footnotetext{
${ }^{5}$ mendidikanakanak.blogspot.com. peran ibu dan peranan ibu.
} 
Kemudian pada awal-awal kehidupan anak merupakan saat yang paling efektif dalam pembelajaran anak dan sangat menentukan masa depannya, karena kapasitas intelektual anak berkembang dengan pesat pada masa-masa awal kehidupannya. Pada saat itu, otak seorang anak mampu menyimpan informasi dengan luar biasa kemudian seiring bertambahnya usia kemampuan itupun semakin berkurang. Disinilah peran penting wanita sebagai seorang Ibu sangat dibutuhkan semenjak anak lahir hingga masa taman kanak-kanak yang merupakan masa keemasan bagi anak.

Jadi dibalik kebaikan, kesuksesan, kegagalan dan kejahatan yang terjadi pada seorang anak semua itu tak luput dari peran ibu yang mendidik mereka. Ibu yang dapat membuat anaknya selalu berbuat kebajikan, sopan santun serta ramah kepada orang lain. Seorang ibu yang dikatakan berhasil apabila berhasil dalam mendidik dan mengasuh sang anak. Ibu yang berhasil memberi pendidikan karakter dan membentuk watak dan mencontohkan perbuatan baik kepada sang anak. Sehingga menciptakan seorang anak yang berhasil dalam karir dan berhasil dalam kategori karakter yang baik, pintar dari segi intelektual dan hebat dalam segi emosional.

\section{DAFTAR RUJUKAN:}

Abu Ahmadi, Nur Uhbiyati, Ilmu Pendidikan (Jakarta: Rineka Cipta, 1991).

blogdetik.com/.../peran-ibu-dalam-mendidik-dan-membangun-karakter-anak. Di akses 18 Okt 2013.

https://muslimah.or.id/6248-peran-ibu-dalam-pendidikan-anak.Di akses 22 Jul 2014.

Irvansyahfa.blogspot.com/2013/03/tafsir-surat-nisa-ayat-9. Di akses 31 Mar 2013.

Kitab B. Marom yang dikutib oleh Zuhairi, dkk, Filsafat Pendidikan Islam (Jakarta: Bumi Aksara, 1992).

Mendidik anakanak.blogspot.com > peran ibu > peranan ibu. Di akses 27 Apr 2013.

News.liputan6.com > News > Peristiwa. Di akses 19 Mei 2017.

Wordpress.com/.../karya-tulis-ilmiah-peran-orang-tua-dalam-mendidik-anak. Di akses 30 Jun 2011.

www.antaranews.com/berita/536495/pendidikan-ibu-jadi-kunci-sukses-anaknya. Di akses 22 Des 2015.

www.kompasiana.com/.../peran-perempuan-dalam-pendidikan.Di akses 3 Des 2012.

zifauziyah.blogspot.com/wanita-awal-sebuah-peradaban-bangsa.Di akses 5 Nov 2013. 